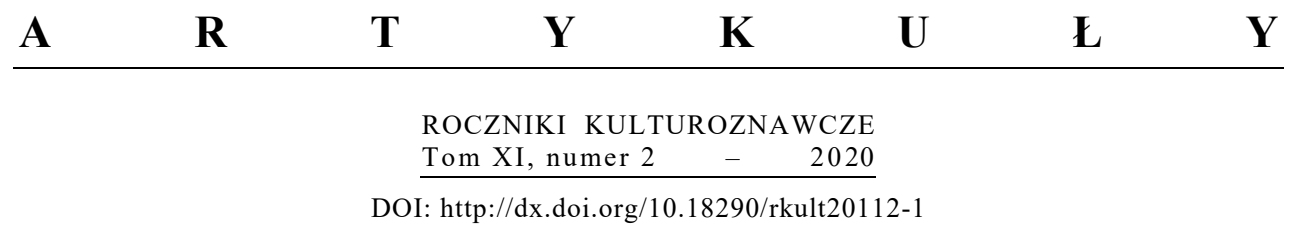

ZOHAR MIHAELY

\title{
ROSENZWEIG'S CRITIQUE OF ISLAM AND ITS VALUE TODAY
}

\section{FOREWORD}

Franz Rosenzweig is best known for the perspective he offers on Christianity in his now canonical, The Star of Redemption (German: Der Stern der Erlösung), first published in 1921. His perspective on Islam in the same work: that the religion represents a "historical plagiarism"; that Mohammed "committed the great plagiarism of revelation"; ${ }^{1}$ that Allah acts with arbitrary belligerence "like an oriental despot"; ${ }^{2}$ and finally that the religions of the East are nothing but a plaything from the point of view of modern Western man (Lieblingen der modern), ${ }^{3}$ were, until recently, perceived in the academy as an aberration in his work, even an embarrassment. Indeed, scholars

Zohar Mihaely, PhD - independent scholar, he recieved his PhD degree from Bar-Ilan University (BIU, Hebrew: אוניברסיטת בר-אילן, Universitat Bar-Ilan) in Israel; address for correspondence-e-mail: zoharm67@gmail.com. ORCID: https://orcid.org/0000-0001-8423-6616.

${ }^{1}$ Franz Rosenzweig, The Star of Redemption, trans. Barbara E. Galli (Madison, WI: University of Wisconsin Press 2005), 192, 127. According to Rosenzweig, Mohammed does not let Allah speak at all. He does not "transmits to the amazed audience the Revelation that took place in secret." The Quran has no introduction such as the biblical "saith the Lord."

${ }^{2}$ Ibid., 128.

${ }^{3}$ Franz Rosenzweig, Zweistromland. Kleinere Schriften zu Glauben und Denken, ed. Reinhold and Annemarie Meyer, in Franz Rosenzweig. Der Mensch und sein Werk. Gesammelte Schriften, Bd. III (Dordrecht: Martinus Nijhoff, 1984), 147. In The Star of Redemption, Rosenzweig suggests that the religions of China (Taoism and Confucianism) and India (he focuses more on Buddhism than Hinduism) have turned the tables by referring to reality not as beginning from nothing and gradually becoming "something," but returned it, through abstracting the existing forces in the world, to the primordial nothingness. For this reason he sees Buddhism as nihilism, and the Buddha as pure nothing. Taoism he calls a type of "primitive atheism." 
like Yossef Schwartz claim that his treatment of Islam is both superficial and limited, stemming from a misunderstanding of canonical Islam, ${ }^{4}$ while Robert Gibbs suggests that Rosenzweig's arguments have no factual basis. ${ }^{5}$ Jean Cahan claims that the reader of the invidious comparison Rosenzweig had drawn between Judaism and Islam is obliged to deal with the complexity of whether comparing cultures and religions is justified or even possible, ${ }^{6}$ while others like the philosopher Hilary Putnam argue that Rosenzweig's analysis provides a mere mockery of Islam ${ }^{7}$ with possibly dangerous consequences, easily appropriated by those calling today for the murder of Muslims (Gil Anidjar) ${ }^{8}$. Yossef Schwartz goes so far as to describe Rosenzweig's Star as an unexploded bomb left over from World War I.

Rosenzweig's description of Islam is similarly echoed among new voices in contemporary Jewish perspectives in discussions of the possibility of intercultural exchange. Rabbi Jonathan Magonet, ${ }^{9}$ for example, takes inspiration for dialogue with Islam from Maimonides (in whom Rosenzweig found an inspiration for a dialogical approach to Christianity alone). Martin Brasser likewise concludes that with Rosenzweig's description of Islam, an interfaith dialogue would not develop. ${ }^{10}$ The first, however, to view Rosenzweig's on Islam seriously was Shlomo Pines, ${ }^{11}$ one of the founders of modern Oriental studies, who was interested in Rosenzweig's sources. Indeed, Shlomo Pines discovered that Rosenzweig's Star was based upon the works of Ignaz Goldziher ${ }^{12}$ as well as Hegel. Although Pines expressed reservations regard-

\footnotetext{
${ }^{4}$ Yosef Schwartz and Gesine Palmer, Franz Rosenzweig. "Innerlich bleibt die Welt eine." Ausgewählte Texte zum Islam (Berlin, Wien: Philo Verlagsgesellschaft, 2003), 155, 146. According to Cristaudo, Schwartz argues that Rosenzweig never read the Hadith literature.

${ }^{5}$ Robert GiBBS, Correlations in Rosenzweig and Levinas (Princeton, NJ: Princeton University Press, 1992), 113.

${ }^{6}$ Jean Axelrad CAHAN, "Rosenzweig's Dialectic of Defiance and Critique of Islam," Journal of Jewish Thought and Philosophy 9, no. 1 (1999): 2.

${ }^{7}$ Hilary Putnam, Introduction to Franz Rosenzweig, Understanding the Sick and The Healthy: A View of World, Man and God (Cambridge, MA: Harvard University Press, 1999), 18.

${ }^{8}$ Gil AnIDJAR, The Jew, The Arab: A History of the Enemy (Stanford, CA: Stanford University Press, 2003).

9 Jonathan MagOnet, Talking to the Other-Jewish Interfaith Dialogue with Christians and Muslims (New York: Bloomsbury, 2003), 147-187.

${ }^{10}$ Martin Brasser, "Rosenzweig und die Karikatur des Islam: Negative Konstruktionen im interreligiösen Dialog," Rosenzweig Yearbook 2 (2007): 152.

${ }^{11}$ Shlomo Pines, "Der Islam im 'Stern der Erlösung.' Eine Untersuchung zu Tendenzen und Quellen Franz Rosenzweigs.” Hebräische Beiträge zum Wissenschaft des Judentums deutsch angezeigt 3-5 (1987-89): 138-148. Appeared also in: Bar Ilan. Jahrbuch der Universität Bar Ilan 22/23 (1987/88): 303-314.

${ }^{12}$ In particular: Ignaz GoLDZIHER, Vorlesungen über den Islam. Heidelberg: Carl Winter's
} 
ing Rosenzweig's analysis, ${ }^{13}$ he considers the Star overall as a well-founded work, especially when read in the context of his general attempt to break free from Hegelian thought, ${ }^{14}$ specifically from Hegel's critical evaluation of both Judaism and Islam, which he termed pejoratively "religions of the sublime" 15 (Religion der Erhabenheit). While Hegel considered both Judaism and Islam inferior to Christianity, he preferred, in principal, Islam to Judaism. ${ }^{16}$ According to Pines, Rosenzweig endeavored to take Judaism out of this Hegelian equation and give it the same status as Christianity.

Universitätsbuchhandlung, 1910. Yossef Schwartz admits that Goldziher is a reasonable source, but that his possible influence doesn't have a solid enough foundation (SCHWARTZ and PALMER, Franz Rosenzweig. "Innerlich bleibt die Welt eine," 120, footnote 14). According to Schwartz, Rosenzweig's interest in Islam that begun in his studential period, was intensified during his military service in the $1^{\text {st }} \mathrm{WW}$, and he expressed curiosity to become more familiar with it one day. While serving on the Estern Front, he imagined that one day he will produce a thick book about Islam which will be critical too. However he never studied Islam systematically, and remained self-taught. He learned also Arabic by himself, though as an object of study as he learned about Judaism, and therefore could not speak it. The Muslim thinker he read the most was Al-Gazahli, see for example a Letter to his parents from April 13, 1917, in Rivka HoRwITZ (ed.), F. Rosenzweig Briefe und Tagebücher [Auswahl], Hebrew edition (Jerusalem: Byalik Institute, 1987), 102 (Schwartz and Palmer, Franz Rosenzweig. "Innerlich bleibt die Welt eine," 130 134). Cahan argues that Goldziher was much more sensitive to the nuances of Islamic ideas on e.g. freedom and determinism than Rosenzweig was willing to allow (CAHAN, "Rosenzweig's Dialectic of Defiance," 20). Pines, too, has noted that Rosenzweig is more radical than Goldziher. Cahan's and Pines' remarks are consistent with Goldziher's authentic views, for example that in a historic evaluation of Mohammed's world, the emphasis should not be on the question whether the content of his revelation was completely original, but rather that he was the first effective (historical) reformer among the Arabs. Ignaz GolDzIHER, Introduction to Islamic Theology and Law (Princeton, NJ: Princeton University Press, 1981), 5-6.

${ }^{13}$ One of these reservations: That he didn't pay enough attention to the nuances between Sunnite and Shiite motifs.

${ }^{14}$ Rosenzweig's doctoral thesis, submitted to the Freiburg University in 1912, was dedicated to Hegel's political philosophy, and was later published as a book: Franz RosenZweig, Hegel und der Staat (Berlin: Suhrkamp, 2010).

${ }^{15}$ In his lectures On Aesthetics, Hegel defines 'a religion of the sublime' as a religion that sees the created world as finite, limited and not self-sustaining, and therefore secondary. That is why man, who exists within this inferior worldly reality, has to praise God wastefully, who exists above it. Only thus can man achieve satisfaction and consolation. Pines argues that Rosenzweig tried to prove that this definition fits Islam but not Judaism. Georg Wilhelm Friedrich Hegel, Vorlesungen über die Ästhetik (Frankfurt am Main: Suhrkamp, 1986).

${ }^{16}$ In his book The Philosophy of Religion, Hegel argues that the Jewish people's special bond with God functions to exclude, even if not polemically, other peoples. That is, in Judaism, other peoples can develop a similar relation to God, but this is not an open objective but rather a kind of inactive duty. Islam on the other hand, sees it as a general objective and duty for all Muslims to convert other peoples to Islam. While Hegel admits that in doing so Islam fanaticizes this objective, he still has a preference for Islam over Judaism thanks to its universal nature, as opposed to Judaism which is primarily particularist in nature. Georg Wilhelm Friedrich Hegel, 
Parallel to this critical trend in the Star's reception, another one developed - balancing the negative image of Rosenzweig's views on Islam. Such a trend is represented in the work of Matthias Lehmann, who argues that Rosenzweig's research merits serious consideration, even though he presents Islam as more homogenous than it is in actual fact. ${ }^{17}$ Wayne Cristaudo argues against Rosenzweig's critics, who ignore, he claims, both the historic-political reality of Islam and the explicit evidence available in Muslim literature. Cristaudo further justifies Rosenzweig's critical approach to Islam since there is "nothing that he says which is not obvious to anyone who reads the Koran with eyes wide open." $" 18$ David Goldmann goes so far as so suggest that Rosenzweig was a kind of prophet, foreseeing the contemporary clash of civilizations. ${ }^{19}$

Another critical controversy revolves around Shlomo Pines' observation that Rosenzweig learned about Islam from Hegel. For example, Wayne Cristaudo argues that Rosenzweig's views on Islam emerge from his judgement that, like modern secularism, Islam denies the idea informing the JudeoChristian Kingdom of God. ${ }^{20}$ According to Yossef Schwartz, however, Rosenzweig's interest in Islam began much earlier than the Star, and had nothing to do with Hegel. ${ }^{21}$ Matthias Lehmann, on the other hand, argues that the

Vorlesungen über die Philosophie der Religion. Hamburg: Felix Meiner Verlag, 1993. See PINES, "Der Islam im 'Stern der Erlösung,' 139.

${ }^{17}$ Matthias Lehmann, "Rosenzweigs Kritik am Islam,” Jewish Studies Quarterly 1, no. 4 (1993/94): 150, 360

${ }^{18}$ Wayne CRISTAudo, "Rosenzweig's Stance Toward Islam: The »Troubling Matter of the Theo-Politics in The Star of Redemption," Rosenzweig Yearbook 2 (2007): 60.

${ }^{19}$ David. P. Goldmann, "Has Franz Rosenzweig's Time Come?" (1999), Jewish-Christian Relations. Insights and Issues in the ongoing Jewish-Christian Dialogue, accessed October 9, 2020, http://www. jcrelations.net/ Has+Franz+Rosenzweig's+Time+Come\%3F.2195.0.html?L =3. Goldmann, who published his insights on Rosenzweig in his column in the daily magazine The Asia Times Online under the pseudonym 'Spengler,' refers to what he calls Rosenzweig's "political writings on Islam" in publications such as Die Neue Levante, Nordwest und Südest and several others, under the pseudonyms "macedonicus." In these publications which came out before the appearance of the Star, Rosenzweig analyzes the state of Islam from a historical-political point of view (unlike the theological point of view on Islam adopted in the Star. For example, he considers the future role of Turkey as a central political force, which will come into being through its internal division into Westerners and Easterners, and serving as frontier in the last campaign between the Judeo-Christian West and the Muslim East. Also see a letter by Rosenzweig to Rudolf Halo from 4.2.1923, in: Franz Rosenzweig. Der Mensch und sein Werk. Gesammelte Schriften, vol. I: Briefe und Tagebücher, 2. Band: 1919-1929, ed. Rachel Rosenzweig and Edith Rosenzweig-Scheinmann with the cooperation of Bernhard Casper (Hague: Martinus Nijhoff, 1979), 889-890.

${ }^{20}$ CRISTAUdo, "Rosenzweig's Stance toward Islam," 80-81.

${ }^{21}$ Schwartz and Palmer, Franz Rosenzweig. "Innerlich bleibt die Welt eine," 62-87. Schwartz, too, refers to Rosenzweig's political writings. 
question of Rosenzweig's sources of influence is irrelevant to the originality of his research, which is founded on his unique philosophy of revelation, making his critique of Islam completely original. ${ }^{22}$

The purpose of the current paper is, first of all, to gain clarity in Rosenzweig's views on Islam in the Star, that in my opinion has been done so far in too fragmented or casual a manner. ${ }^{23}$ Secondly, I place these views in the face of the debate that has developed around them, not just as a cursory review of opinions lined up, but I will also try to evaluate them and create a short discussion that seeks to find if there is something useful for readers who are interested in reading Rosenzweig as a way of making sense of the present. ${ }^{24}$

\section{THE ESSENCE OF ROSENZWEIG'S CRITICISM}

The central argument present in all six of Rosenzweig's discussions of Islam in the second part of The Star of Redemption is that "Mohammed found and took over the idea of Revelation as one picks up a find, that is to say without producing it from out of its presuppositions." 25 By that he may have saved his followers spiritual energies and effort, but at the price of leaving Islam with an "external resumption of these notions without understanding them." ${ }^{26}$ That is, while he had the correct terms - "world, man, God" - he had no understanding of the relations between them. He inherited these terms from Judaism and Christianity as external concepts, viewed by him from the perspective of a pagan world. But they are terms which were

\footnotetext{
${ }^{22}$ Lehmann, "Rosenzweigs Kritik am Islam,", 341.

${ }^{23}$ In this respect, Norbert Samuelson's attempt in his A User's Guide to Franz Rosenzweig's 'Star of Redemption' should be noted positively.

${ }^{24}$ In the scope of the current relatively short work I will not locate Rosenzweig in the context of German Jewish, or Christian views of Islam in his day, nor in any chain of negative Western reference towards Islam. For this, I recommend the excellent review of Robert IRWIN, For Lust of Knowing: The Orientalists and their Enemies (London: Penguin, 2006).

${ }^{25}$ Rosenzweig, The Star of Redemption, 127. That is, while Judaism and Christianity appropriated aspects of Greek thought and transcended it, Mohammed accepted the conclusions of the Greeks without assimilating the concepts himself. Later, for example the Muslim philosophers in the Middle Ages (Averroes, Al-Farabi, Avicenna, Avempace and others) did deal critically with Greek philosophy, indeed had historically significant interpretations of it, but they, too, did not transcend its boundaries. In fact, though they wrote as theologians, they were philosophers, writing philosophy disguised as theology.

${ }^{26}$ Ibid., 187.
} 
not achieved, ${ }^{27}$ since he left them unresolved as they were. The other arguments scattered throughout these discussions are in fact similar manifesta-

${ }^{27}$ Ibid., 185. The basis for this conclusion lies in Rosenzweig's ontology, which he explains in the first and second parts of The Star. Put shortly, according to Rosenzweig, pagan philosophies achieved the knowledge of God-world-man, that is it was able to affirm their existence per se, but nothing more. The philosophers didn't know that something else can occur with them. His criticism of the 'old thinking' is that it started with proves of the existence of God, assigning Him positive characteristics, and peaked at Maimonides negative theology, according to which nothing in particular can be said that God is, but only what He isn't. From there, philosophy had nowhere to go. That is, it started with 'something' and ended with 'nothing.' This criticism of epistemology is also directed at the legacy of Kant, according to which reality (das ding an sich) is unknowable. Rosenzweig rebels against this philosophizing, which always asks first whether I exist, that is - doubts everything. Instead of asking what are the conditions to know what is outside the mind, Rosenzweig asks what are the conditions to know what cannot be known. Such phrasing of the question implies that we should strive for knowledge from a different source than intellect about the 'thing' we know nothing about but that it exists (which is compared knowing a dead idea) in order to reach the comprehension of a dynamic being, a living God. And here he discovered in Hermann Cohen's book Logic of Pure Cognition the concept of the mathematical differential, that is a "relative nothing" (in contrast to a general, absolute nothing). Rosenzweig believed that Cohen himself was not aware of the revolution he brought about (that is, Rosenzweig thought Cohen was not only 'Neo-Kantian,' a follower of an existing tradition, but the harbinger of a new philosophy, which the world would come to know through his The Star of Redemption). This is because the differential shows that something finite, actual, can be produced from a mathematical hypothesis. That is, Cohen produced in his ontology 'something' from 'nothing' (The Star of Redemption, 27-28). While it can't be defined, it opens a possibility for a live, dynamic existence, as vectors do in geometry. In this manner Rosenzweig takes a leap from the 'nothing' of philosophy (Maimonides' theory of negative attributes, or Kant's 'Noumenon,' because the analytical mind can only empty reality) towards an experience of 'something is.' What is required is faith (or belief) in this 'is', and that this faith (in God, world and man) also be a sort of real being. He found a thought that can uncover the mystery of this possibility of something else - which would eventually lead to an active relation between the elements. This thought, which began, as mentioned, in mathematical-logical judgements, is what Rosenzweig calls 'The New Thinking' - speech, since the presence between God and man should not be expressed in hidden (scientific, objective) language, but only by hearing and talking, which are not 'knowledge' but experience. Only in conversation does something happen. The three elements are hidden, that is passive in the proto-cosmos (die Vorwelt) before revelation. They are always there, but as an unturned stone. Exposing them without revelation makes them a lie. The meeting between the elements, for example man and God, does not happen as they are, as if each move toward the other and they meet halfway, and is also not a fusion, because it is impossible that God create man and man create God, but it is enabled only when each of them undergoes internal change, for example that man negates the estranged side in him, which is opened to God's otherness. That is, the negative in one meets the positive in the other. There is a double movement of mutual negation and affirmation. This reversal can be likened to a suitcase, where what put inside first is also the last to be taken out. This internal dynamic was unknown to Mohammed, who likened in his spirit the Judeo-Christian revelation to be something simple, and applied it to Islam in a simplistic manner. The Muslim theology that evolved with time used the data it inherited from Mohammed as much as pagan philosophy can, but not more than that, since Islam 
tions of this central thesis, namely that Mohammed accepted conclusions without understanding the paths leading to them.

Rosenzweig's method is to expose Islam's shortcoming by comparing it to different aspects of Judaism and Christianity - specifically their respective concepts of revelation. To that end, he frequently contrasts motifs from the Tanakh, Talmud and New Testament with those of the Quran.

\section{THE QURAN'S MONOLOGICALITY}

According to Rosenzweig, the fact that the Quran is not a genuine religion of revelation, that is - it "isn't dialogical" - is seen already in the way the Quran represents its own original reception:

The first word of Revelation to Mohammed is:

'Read'!. He is shown the page of a book [...] and Jesus did not leave a single written word for his followers [...] The Book sent down from heaven - can there be any greater distortion of the notion of God himself 'descending', giving himself to man [...] He [Allah - Z.M.] is enthroned in his highest heaven and gives to man - a Book. ${ }^{28}$

According to Rosenzweig, the essence of revelation is not that God "Has done His part" by once delivering from the heavens a text for mortals to "figure ... out themselves." Like Martin Buber, Rosenzweig sees scripture as being oral before being a "book." Indeed, for him, the text is an opening line for a conversation, as in the divine address to Abraham, reinforced by his answer "Here I am." Readers internalize this conversation, carrying it on in their own lives, in their own times. What Rosenzweig understands as the authentic revelation in Judaism and Christianity remains actual by virtue of remaining oral, and not merely a mute speech inside a book. Those converting to Islam, by contrast, open the Quran and remain silent and sub-

is missing the crucial phase of revelation, where the hidden God becomes a revealed, loving God, and therefore Islam cannot completely follow the path that leads to redemption (on Rosenzweig's ontology in detail, see Lehmann, "Rosenzweigs Kritik am Islam," 341-348; Stéphane MosÈs, System and Revelation: The Philosophy of Franz Rosenzweig (Detroit: Wayne State University Press, 1982), part 2; GibBS, Correlations in Rosenzweig and Levinas, 46-56; Norbert M. SAMuelson, A User's Guide to Franz Rosenzweig's 'Star of Redemption' (Abingdon, Oxon: Routledge, 1999), 3-22.

${ }^{28}$ Rosenzweig, The Star of Redemption, 180. The word Koran is spelt Qur'an in Arabic, and comes from the word qara'a, which means: to read, read aloud. The Koran is thus the book that is to be read or recited. Appropriately, the first word of Allah's revelation to Mohammed, recorded in the oldest Koranic Sura (no. 96) is: "recite" (iqra). 
missive, with the space left by what Rosenzweig calls the 'love-dialogue,' filled, as we will see later, with something else altogether.

\section{THE MEANING OF THE MIRACLE}

Islam sees the Quran as a miracle unto itself - in the sense that it is a super-human creation. Rosenzweig, however, distinguishes between miracle and magic. A miracle is not simply any unexplained phenomenon, but rather an "omen" (Zeichen) which, predictive of the future, expresses divine providence. ${ }^{29}$ In a Jewish context, for example, the biblical narrator emphasizes that the miracle of the exodus was already given to Abraham in prophecy. In parallel, in Christian typology we see that events from the preChristian era are interpreted to anticipate the future coming of Jesus Christ. The Quran, by contrast, is similar to a Talmud with no key or commentary, or a New Testament without an Old Testament to foresee it. Mohammed, after all, found the Quran ready-made, not within the context of a divine plan of salvation, as in the eschatological visions of both Judaism and Christianity, working from the beginning of history to its end. ${ }^{30}$

According to Rosenzweig, wondrousness and magic are in fact both modern ideas. To us, it seems, because of the influence of modern science, there is a need for a law of nature as background against which a miracle distinguishes itself. But for pre-scientific readers, the miracle defined itself not only by transcending the natural order, but because it was an unexplained phenomenon, expressing providence - a fulfillment of a divine promise. Miracle and prophecy, in both Jewish and Christian contexts go hand in hand. Further, for Rosenzweig, the proof that magic and omen are on different planes is that there are two distinct and different ways of evaluating their veracity. The Torah reads "Thou shalt not suffer a witch to live," while the prophet is to be investigated, to see if the omen and sign he spoke of will come to be. ${ }^{31}$ The magical and miraculous are evaluated by completely different criteria. Therefore, even if we say that the Quran's finish, beauty, wisdom and richness are "superhuman," this is simply an appeal to authority which, for Rosenzweig, has no theological significance. ${ }^{32}$ A religious "mi-

\footnotetext{
${ }^{29}$ Ibid., 127

${ }^{30}$ Ibid.

${ }^{31}$ Ibid., 104-105.

${ }^{32}$ Rosenzweig's argument is consistent with that of Rabbi Jehuda Halevi (The Kuzari, first article, paragraph 6) that the notion that the Quran is a superhuman creation remains uncon-
} 
racle" is therefore only understandable, even if only subjectively, inside the frame of the language of faith. But in Islam, critically for Rosenzweig, it is not understandable even in its own language of faith. The Quran, therefore, is at most an act of magic, a "magical miracle" - the power of which is not in being told in advance, but in being without any explanation. Its author, Mohammed, was, therefore, for Rosenzweig, not a prophet but a magician.

\section{CREATION AND PROVIDENCE}

According to Rosenzweig, Allah created the world capriciously, not out of a will subordinate to logical necessity. This capriciousness is expressed in Allah's creating the world not as to supply the necessary, that is, He did not use his authority to put forth a law to help the created (despite the seemingly zealous attention the Sharia pays to the details of sins and punishments). Rather, He used His freedom to act according to his whim mood, as a pure display of force, after the style of what Rosenzweig calls "the power of an oriental despot." ${ }^{33}$ In other words, Mohammed's perception of God is that of an omnipotent creator who could have just as well avoided creation - for $\mathrm{He}$ is "wealthy without any world." ${ }^{34}$ As with oriental despots, His power and ability are proven by themselves, even more powerfully because of by His removal from any direct earthly connection, the absence of any link to the created world. Unlike the biblical God, represented as occupied in cultivating connections to the world and men, Allah's distance does not enable mortals to develop any relationship to Him, definitely not one of love. What this means for man and creation is that Allah's capricious behavior lacks any consideration of distinguishing right from wrong. That is, His capricious nature is a symptom of an extreme in which right and wrong are one and the same. ${ }^{35}$

Rosenzweig compares such freedom to that of Judaism, where the sages typically frame divine potency around the question of whether God created the world according to the measure of justice or the measure of grace. In other words, the sages ascribe a moral judgement to the biblical God. As Matthias Lehmann explains, God's creative ability may be all-powerful, but

vincing, since it cannot be verified by anyone who does not speak Arabic. A book which was destined for all of humanity requires objectivity that goes beyond a specific national sensibility or perspective.

${ }^{33}$ RosenZweig, The Star of Redemption, 128.

${ }^{34}$ Ibid.

${ }^{35}$ Ibid. 
His is not an arbitrary power. That is, He can do everything He wills - but ultimately He would only will what he must. That is, the divine is bound by necessity. ${ }^{36}$ As Martin Brasser puts it - the God of authentic revelation is free and bound at the same time, while Allah is seemingly only free. ${ }^{37}$ In terms of providence, since He knows no need to act or refrain from acting, each and every one of His acts is derived from a momentary state of mind related only to itself. That is, such a divine act denies the moment preceding, just as it refrains from being a binding precedent to the moment after it. In Rosenzweig's words: "for arbitrariness, creating and destroying are the same. In the same movement it glories in both and demands of its believers to venerate both, or rather precisely only: to fear both equally." 38 For Rosenzweig, this is a preeminent example of Mohammed's lack of understanding of a concept appropriated from Christian and Jewish contexts.

In this case, Mohammed is said to confuse revelation with creation: Allah is constantly involved in the lives of mortals, like a maker is involved with his product. That is, Islam asserts constant particular providence, which in Judeo-Christianity exists only at the time of revelation. ${ }^{39}$ The understanding of providence as a continuous creating-intervention denies any possibility of harmonizing reality, of a relation between the creator and created. ${ }^{40}$ Being all powerful,Allah created everything arbitrarily and at the same time. However, due to His despotic nature, even in this arbitrariness he does not lose control of the created, even for one moment. He does not allow created beings freedom, knowing everything that will happen to each and every one of them. According to Shlomo Pines, Rosenzweig's description of Allah is consistent with the Hegelian conception ${ }^{41}$ - that even if Allah acted in some way dictated by logic or necessity, it would only be a coincidence. For this

\footnotetext{
${ }^{36}$ Lehmann, "Rosenzweigs Kritik am Islam,” 343.

${ }^{37}$ BRASSER, "Rosenzweig und die Karikatur des Islam," 146.

${ }^{38}$ RosenZweig, The Star of Redemption, 129. Such a criticism is identical to his criticism of idolatry: the infinity of the pagan world (die Vorwelt) is poor because it is 'ever enduring' (immerwährend), and is only a meaningless repetition of itself. Each moment is pushed forward by the previous one - there is no renewal. By contrast, in religions of revelation (Christianity and Judaism), there is an end which renews them at all times. For Jews and Christians, individual moments are part of the larger patterns where infinity exists not only as a concept or an idea (an abstract 'form'), but in actual practice through the yearly cycle of prayers and holidays.

${ }^{39}$ Rosenzweig, The Star of Redemption, 132-134.

${ }^{40}$ Ibid., 134.

${ }^{41}$ In Georg Wilhelm Friedrich Hegel, Lesungen über die Geschichte der Philosophie. Zweiter Theil: Die Philosophie des Mittelatlers, 1 (Frankfurt am Main: Suhrkamp, 1986).
} 
reason, Rosenzweig calls Allah's behavior unreasonable (unvernünftig), ${ }^{42}$ by which, according to Shlomo Pines, he meant arbitrary. ${ }^{43}$

In contrast, in an authentic revelatory religion the desired relation between the world and the creator is, according to Rosenzweig, a continuous renewal with its own internal necessity. The world is imbued with a purpose and therefore each moment has meaning-after all, it follows from the previous moment towards a purpose - redemption. This relation between the constant-continuous creation to the one before it and after it, defines divine providence. The atomism of Islam, however, shatters the original JudeoChristian idea of providence into, what for Rosenzweig are so many acts of magic, with Allah watching over each one. In this view, in the dominant doctrine of Islam's orthodox philosophy from as early as the Middle Ages, the rules of nature are shattered, creating a reality where each detail is created from nothing at every moment, like the infinity of paganism, where each moment is a new beginning. For Rosenzweig, this atomistic conception of time is an essential part of Islam, rather than an ephemeral religious fashion. ${ }^{44}$ In his words:

The idea of the 'renewal' of the world safeguarded for the individual his relationship with one Creation and consequently with the unity of existence $[\ldots]$ the conception of providence in Islam destroys any possibility for such connection [...] In spite of the idea of the unity of God, posited vehemently and proudly, Islam slips into a monistic paganism, if you will allow this term. At every moment God himself competes with God himself, as if one were in the gaily-colored heaven of the gods of polytheism amidst their conflicts. ${ }^{45}$

The purpose of the authentic Judeo-Christian process of love is therefore, according to Rosenzweig, that the world must be entirely filled with life. Instead of only a few sources of life, described (in Rosenzweig's colorful expression) as raisins in a cake, the world should be alive in all its points. If it is not, it is only because the world remains unfinished. In this context,

\footnotetext{
${ }^{42}$ Hegel, the unreasonableness of Allah's behavior emerges because of the atomistic nature of Allah's creation in which every atom (or created thing) comes and goes and another takes its place, and so on, arbitrarily and without any direction that might link them into a logical purpose. — Georg Wilhelm Friedrich Hegel, Vorlesungen über die Geschichte der Philosophie. Die Philosophie des Mittelalters, (1) Die Arabische Philosophie, in Hegel sämtliche Werke, Bd. 19 (Stuttgart: Fromanns Holzboog, 1958), 127-129.

${ }^{43}$ Pines, "Der Islam im 'Stern der Erlösung'," 140.

${ }^{44}$ Rosenzweig, The Star of Redemption, 134. On the atomistic conception of time, Rosenzweig means the normative $11^{\text {th }}$ century theology of Al-Gazahli; indeed, Al-Gazahli, who was Sufi, was the Muslim philosopher Rosenzweig read most frequently.

${ }^{45}$ Rosenzweig, The Star of Redemption, 134
} 
Rosenzweig repeats his claim that Allah's creation and the acts of his messenger are acts of "magic." 46 About this, Wayne Cristaudo comments disparagingly that Allah and Mohammed were "made for each other" - that is, they are both a species of Superman - each having everything and being everything, appearing to love the same things. While Mohammed is not a deity, all of the Quran's descriptions of him create the impression that the words of the prophet and the word of God are inseparable, that every truth in revelation must come from him, as if the rest of Allah's created world cannot be trusted. Mohammed needed to have been perfect, transcendent and removed from earthly affairs, or Allah would not have chosen him to be his prophet. ${ }^{47}$

\section{THE ELEMENT OF LOVE}

According to Rosenzweig, the Judeo-Christian God gives himself into every moment in an act of boundless love, forgetting in every moment all others. Though in the end, He will love all, until then He must love each separately. That is, in the future all that is still not surrounded (or: seized) will eventually be surrounded as well with love. This is the idea of foreshadowing, the "not yet" (noch nicht) characteristic of the Jewish and Christian eschatology. ${ }^{48}$ In contrast, Allah's love is universal (Alliebe), in the sense that it is given in advance and at once ${ }^{49}$ and for always to all of mankind (not only Arabs). Since such love floats high up and radiates at the speed of light to all times and persons, there can be no personal relationship - neither can it here be amplified, nor be more bountiful. In short: "Islam knows a loving God just as little as it does a beloved soul," ${ }^{50}$ with, in fact, according to Rosenzweig, Allah revealing Himself as more merciful than loving.

\footnotetext{
46 "The journey through the seven heavens is not a proof of divine grace, but a miraculous act realized by the prophet himself" (Ibid., 179).

${ }^{47}$ Cristaudo, "Rosenzweigs Kritik am Islam," 67, 70

${ }^{48}$ Rosenzweig, The Star of Redemption, 178, 235-236. On Jewish and Christian conceptions of time: "If it seized everything all at once, how would it differ from Creation? For Creation, too, created everything all at once, and so became the everlasting past. A love which would have seized everything to begin with would only be 'to begin with', only a past" (ibid., 178).

${ }^{49}$ The factuality of the act of revelation in Islam is like that of the act of creation in Judaism and Christianity, that is, it is a general, one-time act, unlike providence. Allah is constantly involved in the lives of his created, like a maker is involved with his product. That is, He has a "particular providence over creation," which in Judaism and Christianity only maintains at the event of revelation itself (RosenzWEIG, The Star of Redemption, 133-134).

${ }^{50}$ Ibid., 186. Cristaudo mentions that while love is a dominant motif in Sufi poetry, Sufism is still to a large extent a foreign neo-Aristotelian-Platonic hybrid implanted inside the Muslim world.
} 
The word "mercy" begins every Sura. But mercy is not love, because love seeks to engage people, elicit a dialogue, while mercy does not expect an answer. The meaning of this universality is that Allah has "done his part" by sending prophets to all peoples, not only Arabs, thought others may have rejected Him. In order to provide a foundation for this idea, Muslim theology invented what Rosenzweig calls the "fiction" that Adam, the three patriarchs, the prophets of Israel and Jesus were Muslims who taught Qur'an. ${ }^{51}$ Unlike Hegel, who saw Islamic universalism as a point of superiority over Judaism, ${ }^{52}$ Rosenzweig saw such universalism as entailing a shortcoming. For Rosenzweig, Allah's relationship to the creation was never particularistic: Allah cannot appear in front of his people (or peoples) and say that $\mathrm{He}$ knows them from all the families of the earth with all of their inequities, as God does in Amos 3:2. Further, the idea that the sins of man merit the love of the god; that $\mathrm{He}$ is able to show affinity to human weakness as well; and that at times He chooses people for this very reason (e.g. Judah and David), manifests a form of "divine humility foreign to the God of Mohammed." 53 Although the Jewish as well as the Christian God is universal, He is not so in an abstract sense, but has an actual relation to particular people, and even before that- in His personal covenant He has made with the patriarchs.

\section{THE FALLACY OF REPENTANCE AND THE CONVERSION OF LOVE INTO DUTY}

Unlike what Rosenzweig sees as the revolution of repentance in Judaism and Christianity (die innere Umkehr), expressed in denying the closed, tragic autonomy of the individual and opening to God and the other's otherness for Rosenzweig the great secret of authentic faith ${ }^{54}$ - the process of converting to Islam does not change a person internally. Muslim conversion simply entails an external admission that Allah exists, and that there is a duty to

That is, Sufism is a wide category which includes converts alongside ardent believers in the Shari'a, and is still treated with suspicion by many in the Muslim world (ibid., 73).

${ }^{51}$ Rosenzweig's analysis here is consistent with Goldziher, who wrote that Mohammed used the history of the Old Testament (especially Aggadic material) and took from it examples of the fates of ancient peoples who resisted the warnings sent to them by Mohammed in the name of Allah. GolDziner, Introduction to Islamic Theology, 8.

${ }^{52}$ As mentioned above, because of this universalism, Hegel preferred Islam over Judaism's exclusivist tribal nature.

${ }^{53}$ Rosenzweig, The Star of Redemption, 180.

${ }^{54}$ Ibid., 185. 
spread the knowledge of His authority in the world. That is, Islam is satisfied with a one-sided surrender to Allah. ${ }^{55}$ Further, since Allah does not turn to anyone in specific, the Muslim does not open up to receive love, but rather fills his being, which remains closed, with the manifold duties that are imposed upon him. Love has been replaced in Islam by "religious duty," a heteronomic ethics ${ }^{56}$ which negates Judeo-Christian ethics, because it is not based on a personal relation, and emphasizes obedience instead (Gehorsamkeit). ${ }^{57}$ Judaism and Christianity have a common vision of a world eventually to be united in love, based on love of the neighbor as a fundamental element of revelation. In both religions, according to Rosenzweig, social harmony is as important as bringing the individual closer to God. Islam, by contrast, emphasizes worship, where not love but obedience and duty are meant to advance the kingdom of Allah in the world through Jihad.

Rosenzweig thus distinguishes between the Judeo-Christian ideal of the "holy" man, attentive in his way to God's continually renewing advice, and the Muslim ideal of the "pious" man. The latter's actions are a result of automatic obedience to an objective historical law laid down in a particular time ${ }^{58}$ and his way is reduced to the spreading of a one-time, unequivocal message: Jihad. ${ }^{59}$ Surprisingly, given his overall perspective on Islam,

${ }^{55}$ What is missing in this surrender is the dialectical phase (the reversal) from rebellion to peace. Islam thus provides a perfect, mysterious book with no interpretation. Rosenzweig's discussion of rebellion in the Star is the continuation of a long Jewish tradition of negotiating with God, reaching back to the Tanakh, with the book of Job and Abraham in Sodom (CAHAN, "Rosenzweig's Dialectic," 12-13).

${ }^{56}$ Rosenzweig, The Star of Redemption, 231.

${ }^{57}$ Ibid., 232-231. Or as Cahan put it, the relation between Allah and the Muslims is not one of love, but a slave-master to a slave, or maker and his product. CAHAN, "Rosenzweig's Dialectic," 11.

${ }^{58}$ Rosenzweig, The Star of Redemption, 233. "Whereas in the love of the neighbor, it is the rupture, unceasingly begun over again, of the lasting form of the character through the always unforeseen irruption of the act of love. What this act consists of in the particular case cannot be told in advance, for precisely this reason. It must be unforeseen. If it could be pointed out in advance, this would not be an act of love" (ibid., 232). The implication of this simple, impersonal and obedient self-effacement, according to Rosenzweig, is that "to the figure of the saint there belongs the saint's legend. In Islam there are no accounts of the saints. Their memory is honored, but this memory is without content, it is the memory of piety in general" (ibid., 233-234).

${ }^{59}$ In The Star of Redemption, Rosenzweig explains why the Judeo-Christian commandment cannot fall into heteronomic legalism which requires blind obedience like the Shari'a, as follows: the positive aspect of the Ten Commandments, concerns only ritualistic activity which expresses love to God, and not to moral (normative) commandments, phrased as positive laws. Even the commandments detailing the love of the neighbor, which are given in the negative form ('Thou shall not') in both Judaism and the Christian canon, a structure which is supposedly the closest to the form of what we call 'law,' are not general as are Kant's, since they only define a boundary of activity and not the action itself. That is, they instruct the person what not to do out of countless 
Rosenzweig observes that at least during the Middle Ages, Islam was more humane and tolerant than other religions of the time, including Christianity. As Rosenzweig argues, Islam demanded tolerance long before Christian Europe discovered the term. Moreover, the Christian interpretation of neighborly love, for Rosenzweig, was contradicted by its practice - the Church's conception of "religious war" and its consequent trials of infidels. ${ }^{60}$

\section{ISLAM AS THE PRESENT-DAY HEIR \\ OF THE PAGAN ETHICS}

Defining Islam as religion of duty, and thus elevating duty and obedience as supreme values, for Rosenzweig, has very definite moral repercussions primarily in making Muslim ethics a pagan one. The emphasis on submission and self-effacement in relation to Allah may seem to entail peace of mind, but as a merely outward gesture, represents, for Rosenzweig, only a desire for conquest. Rosenzweig explains that the world Shalom, peace, which in Hebrew means a divine tranquility in the present, has become in the Arabic form Islam, meaning a reagent, an incentive to action. That is, while the two words seemingly stem from the same root, S.L.M, their meanings in Judaism and Islam are opposite: the commandment "Haslem" in Islam does not mean "be tranquil," "relax," but remains forever as a commandment for the completion of an action that must be performed time and again at every moment. ${ }^{61}$ Fulfilling this duty is not merely a symbolic matter, but has a value in itself - the achievement.

According to Rosenzweig, Islam arrives at a kind of pagan ethics, what he calls "the ethics of achievement" (Ethik der Leistung) ${ }^{62}$ similar to that of Stoicism, (in decline at the time Islam's emergence), or even the NeoPaganism of "Virtus" still current today. For all of these, piety, which is the

number of permitted activities. Therefore, the more exalted the human act in the world, for both Judaism and Christianity, the more it is a free act of love which cannot be imagined in advance. Ibid, 232.

${ }^{60}$ Ibid.

${ }^{61}$ The Muslim's self-completion (following the commandment 'haslem') is always forced. RosenzweIG, The Star of Redemption, 185, 232-234.

${ }^{62}$ Ibid., 186. Leistung in German is power, that is, the rate at which work is done. In other words, this is an ethic of productivity, is a mentality in which the person is always in pursuit of achievements, as if he is driven by someone else: how much did you do today? In some English translations of The Star of Redemption, the term has been understood to mean that Islam is a religion of action. 
true measure of religious achievement, indeed has become an achievement in itself, namely measured by the difficulty and scale of obstacles which have to be overcome. That is, in the case of Islam, the measure for the evaluation of a moral act is the measure of submission to Allah required to perform it. ${ }^{63}$ The more difficult the act of obedience, the more it is valued. Therefore, while in Islam, each act is considered in itself, by contrast, in Judaism and Christianity, the single moral act is considered, at most, a sign of the general state of an individual strength of faith, the force of its hope, its faithfulness to God and so on. In Judaism, specifically, the fulfilment of any command light or grave carries a similar weight: "And be thou careful with a light precept as with a grave one, for thou knowest not the grant of reward." ${ }^{64}$

\section{ISLAM AS A "RELIGION OF PROGRESS"}

In the foregoing examples, Rosenzweig examines Islamic philosophy and its ethic from the point of view of revelation, which foretells the beginning of redemption. In his sixth and last discussion of Islam in the Star, placed in the third book of the second part, Rosenzweig examines Islam from the point of view of salvation - through seeing history as moving towards its end in the Judeo-Christian idea of the coming of the "kingdom" (Die Ewige Überwelt). What is notable in this comparison is that only here does Rosenzweig create an analogy between Islam and modern philosophy. Rosenzweig wants to argue from this analogy that the modern "concept of progress" both in history and Islam, despite their differences, share a similarity - their common inability to contain their respective visions of salvation in the JudeoChristian Kingdom of God. Christian thought, Rosenzweig explains, continually reveals to its believers how God acts in history, showing the internal necessity of the growth of the Kingdom of Heaven despite the recurring disappointments from historical events proving that God is unfathomable (a principle Christianity shares with Judaism). Muslim scholars, by contrast,

\footnotetext{
${ }^{63}$ Ibid., 186. Every act is considered in itself, while in authentic faith a number of acts are joined together as a marker, as in Judaism, of the general state of the soul. According to Rosenzweig, this 'work-ethic' is reflected clearly in Al-Ghazali, in his comparison between Jesus's asceticism and Mohammed's sensuality. Al-Ghazali praises his prophet over the Christian one, presenting Mohammed as greater than Jesus. For Al-Ghazali, the latter's merit was greater in that his desire for God was greater than fulfilling his urges. Jesus, by contrast, avoided this fulfillment since the passion of his piety was not strong enough and was in fact in danger of being extinguished.

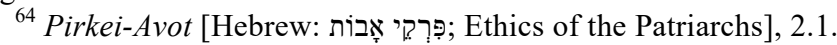


had a sincere, scientific interest in history (an interest which appeared with them for the first time since the ancients), an interest that is even somewhat modern, albeit without a "historical-philosophical background," that is a distinct historical interest such as that of Christian theology. This is reflected, characteristically in Islam, in two separate motifs: the doctrine of "Imams," which contradicts the internal necessity of the growth of "The Kingdom" in history ${ }^{65}$, since every period since Mohammed, that is every century, ${ }^{66}$ has its own Imam directing the faith of his generation in the "straight and narrow." But, according to Rosenzweig, there is no connection between the periods, no development, and no spirit that moves through all of them uniting them with the exception of the legacy of Mohammed. Another doctrine therefore joins this one - the "Ijma" (or: consensus) namely that every generation has no choice but to rely on the agreement, ensured by the power of the authority of Mohammed's promise that his followers would never unanimously concur in an error. In other words, these two doctrines - of the Imam and Ijmaare an expression of the specificity of every historically independent Muslim community, and in truth Islam itself - that is, its independence from both past and future. While every community is always new, and has a direct relationship to Allah no matter what the period, Muslim history shows no organic or slow continuous growth. ${ }^{67}$

The meaning of Mohammed delegating his authority to the present Imam, as well as the authority of the consensus in the present, is that for Islam the past controls the present without being continuous with it. For precisely this reason Islam speaks at such length about the model of Mohammed (or the Sunnah - the original spirit of the first generation of Muslims). That is, Muslim law persistently attempts to base itself directly on sayings by its founding prophet, precisely because it cannot truly preserve its past. These two Muslim doctrines are therefore unlike the authority of Jewish rabbinical ruling (which relies on the verses 'you have but the judge that is in your days,' and: 'after many to wrest judgement'). Although for the sages, the present rules over the past, ultimately, the rabbinic mechanism of handing down authority relies on the past and - through memory - preserves it as if it were present. That is, while rulings in present times stems from purely

\footnotetext{
${ }^{65}$ Rosenzweig, The Star of Redemption, 242. According to Pines, Rosenzweig's explanation of these doctrines was influenced by Goldziher's books Vorlesungen über den Islam, 314, and Introduction to Islamic Theology, 48-50, 106.

${ }^{66}$ RosenZweig, The Star of Redemption, 242.

${ }^{67}$ Ibid.
} 
formalistic interpretive guidelines governed by logic, they are considered as if given directly to Moses on Sinai. ${ }^{68}$ In parallel ways, the conceptions of authority implicit in the Islamic doctrines of Ijma and Imam are also different from the dogma of the 'infallible church' - as the Church is considered to be a living custodian of the teachings of Jesus and the apostles, a continuous living tradition independent of new agreement or covenant.

Through this exploration of authority in Islam, Rosenzweig goes on to delineate the common elements between Muslim doctrines and modern conceptions of historical progress. In contrast with the Judeo-Christian conceptions of the necessity of the coming of the "Kingdom" (though it cannot be known in advance), the Islamic idea of the future is "poisoned at the root," 69 because the idea of foreshadowing, namely that the kingdom is already at hand, that every moment becomes eternal because the eschatological end (the coming of the messiah) ${ }^{70}$ is already expected- is eliminated in Islam and idealism. In modern idealism (as in Hegel's, for example), the infinite progress of history will always "miss" its end, because it has no end-the future will always stay in the future. The distinguishing feature of the future in the Judeo-Christian notion of the "Kingdom" is that eternity is not so long a time - it can be even today ("By this you shall know that the living God is among you," Joshua $3: 10$ ). Eternity is a future which is present without ceasing to be a future. ${ }^{71}$ While the "idea of modern progress," by contrast, does not know "eternity" but rather "infinity," where every moment is assured to have its turn. ${ }^{72}$ Despite their seeming similarity, with their common element of a certain kind of continuity, for Rosenzweig, one can easily illuminate the difference between a believer in the "Kingdom" and an idealist who believes in "progress," through posing the following question: Do you believe the ultimate ideal purpose can come even at this very moment $?^{73}$ For the Muslim, the answer would probably be: yes. For Islam does see the world as an object of redemption, and Allah's way intends to lead the believer to a true epoch in time. But for Rosenzweig, this is distinct from Judeo-

${ }^{68}$ Ibid., 243. That is, as an unmediated source of the Torah from Sinai.

${ }^{69}$ Ibid.

${ }^{70}$ Only because of this foreshadowing does the moment becomes the time of the infinite, since every moment is a foreshadowing of redemption, the very fact that every moment could be the last makes it a starting point for the future in the form of a sequence in which every link is anticipated by the first.

${ }^{71}$ Rosenzweig, The Star of Redemption, 241.

${ }^{72}$ Ibid.

${ }^{73}$ Ibid., 244 
Christian tradition. For while through the Judeo-Christian's conception of the "Kingdom" believers are lead forward in history through an empowerment of their vitality, in Islam there is no corresponding sense of advancement. True, there is always something new in Islam, new historical periods, but each renewal is not through a gradual movement towards a telos. That is to say that although every time period has a direct relation to Allah, since there is no sense of historical continuity, Islam in reality only has a past. This approach - that every period has a direct relation to Allah — is parallel to that of the historian who only strives to understand what has already happened. ${ }^{74}$

To conclude, as in the modern idea, in the doctrine of the Imams and the concept of Ijma, moments in time are laid out one after another in infinite fashion neither adding nor detracting from one another or from the overall view of history. Even though each period/link in itself is contemporary, when they are all brought together they seem not as a future but rather as a past. The notion of foreshadowing is eliminated in the doctrine of the Imams in the same way that it is eliminated in the conception of the future implicit in the modern idea of progress - the latter based on epochs (Epochen) - the times of which join to an infinite series which is not "eternal" as the existence of each epoch is as certain as the epoch following it. For these reasons, Rosenzweig considers Islam "the religion of progress.",75

Wayne Cristaudo, adding to this analysis, suggests that from a naturalistic viewpoint (such as that of Hegel, for example), the idea of the Kingdom is an impoverished one which should be discarded, since it is not universal. From the point of view of Islam, the Judeo-Christian expectation of the "Kingdom" is sacrilegious, since it is in essence a wish to press God (or the Messiah) to arrive before his time. History will continue, and Allah will come only when He is ready, and we must wait. This "not yet" aspect of revelation leaves a place for something to awaken. But the notion that reality comes into being and love moves things forward, both emphasized in Judaism and Christianity, endanger Allah's all powerful status in the perfect, magical Quran, because they show the world to be imperfect. ${ }^{76}$ Matthias Lehmann remarks further that Rosenzweig's discussion of the doctrine of the Imam and the modern concept of progress is the latter's answer to Hegel who claims that the "religions of the sublime," Islam and Judaism, are

\footnotetext{
${ }^{74}$ Ibid.

${ }^{75}$ Ibid., 242-243

${ }^{76}$ Cristaudo, "Rosenzweig's Stance toward Islam,” 61, 81, 82, 84
} 
merely a stage in the development of the absolute spirit, a stage superior to natural, pagan religion, but inferior to Christianity. ${ }^{77}$

Shlomo Pines expresses a number of important reservations in relation to Rosenzweig's analysis of Islam. According to Pines, Ignaz Goldziher distinguishes between the Sunnite church of Ijma, and the authority of Shi'ite Imams. In Rosenzweig's hasty reading, Pines argues, he overlooked this distinction, as well as Goldziher's further insight that although according to the Shi'ite doctrine, every age must have its own Imam, ${ }^{78}$ an "age" does not necessarily entail a hundred year period. In addition, Rosenzweig's assertion that there is no relation between periods (no continuity between one and the other) is also, Pines claims, results from a misunderstanding of Goldziher, who in actual fact asserts a close connection between the chain of Imams, necessitated for theological reasons. Matthias Lehmann supports Pines' reading, as Ignaz Goldziher indeed points to the division between Shi'ites and Sunnites (and many other divisions), apparently unnoticed by Rosenzweig. Lehmann, however, does leave room for the conjecture that Rosenzweig considers the term "Imam" to refer simply to a generic religious leader, not belonging to any specific denomination. In any case, Matthias Lehmann sees this as part of Rosenzweig's tendency to provide too a general and homogenous picture of Islam, in the process leaving out important historical details. ${ }^{79}$

Shlomo Pines' more significant reservation regarding Rosenzweig, however, is that had the latter provided a more nuanced representation of Islam, the assertion of the parallels in the Star between the doctrine of the Imams and the modern idea of progress would have also been shaken. If Rosenzweig had been looking for a parallel to the idea of progress in a positive sense, he could have found evidence for this in Ignaz Goldziher's explanation that the Ijma gave Islam an opportunity to develop, and that the doctrine provided a correction to the tyranny of the dead word (as Rosenzweig saw the Quran) through the bolstering of personal authority. That is, Goldziher argues that in the past, the Ijma actually proved Islam's adaptability to the changing times, and would have served a similar function if had it continued to be employed ${ }^{80}$ Pines, however, argues that unlike in Goldziher's Liberal-

\footnotetext{
${ }^{77}$ Lehmann, "Rosenzweigs Kritik am Islam," 359.

78 I. GoldziHer, Introduction to Islamic Theology, 176; PINES, "Der Islam im 'Stern der Erlösung,", 147.

${ }^{79}$ LehmanN, "Rosenzweigs Kritik am Islam," 357.

${ }^{80}$ Pines, "Der Islam im 'Stern der Erlösung'," 147; GolDzIHER, Introduction to Islamic Theology, 52. Similarlly, Rosenzweig seems to have overlooked many of Goldziher's discussions
} 
Progressive approach, Rosenzweig's wariness towards the modern concept of 'progress' made him understand Goldziher's discussion of the Ijma as pointing to a trend in Islam similar to modern 'progress'. This similarity justified for Rosenzweig a negative evaluation of both this modern trend and Islam as a whole. ${ }^{81}$ Similarly, Matthias Lehmann argues that Rosenzweig's perception of time and history in Islam is flawed since, as Goldziher points out, Muslims too expect a day of judgement and the coming of their savior, the Mahdi, in contrast to the worldview of paganism where the past is infinitely dragged forward. ${ }^{82}$

\section{ROSENZWEIG AND CONTEMPORARY DEBATE OVER ISLAM}

Before reflecting upon Rosenzweig's possible contribution to different contexts of current conversations about Islam, I provide a general summary of Rosenzweig's view on Islam - distilled in his comment that Islam is in fact a "remarkable case of world historical plagiarism", ${ }^{83}$ or simply an unsuccessful imitation of Christianity and Judaism. ${ }^{84}$ As Moshe Schwartz remarks, unlike Yehuda HaLevi or Maimonides, who saw Islam as a religion closer in spirit to Judaism than to Christianity, ${ }^{85}$ Rosenzweig thought that Islam deteriorated into 'Paganistic monotheism' ${ }^{86}$ (Monisteisches Heidentum). Rosenzweig's expression, while paradoxical, expresses well the conflict in terms of what was for him Islam's peculiar mixture of monotheism and idolatry. Indeed, for him, the Muslim's confession of faith - that "Allah is the God" - is in actuality, an expression of lack of faith (ein Unglaubensbekenntnis). ${ }^{87}$ To support this view, Rosenzweig remarks that according to Nicholas of Cusa, even a pagan (or, in our days, an atheist)

about the continual struggle of Islamic movements throughout history against fixed interpretations of the law, in the search for more flexible (or less fanatical) theories and practices (for example: ibid., 232, 233, 234, 236). Goldziher emphasizes that the Ijma was a profoundly significant principle that more than any other characterizes the development of Islamic law (ibid., 50).

${ }^{81}$ Pines, "Der Islam im 'Stern der Erlösung'," 147.

${ }^{82}$ Lehmann, "Rosenzweigs Kritik am Islam,” 359.

${ }^{83}$ Rosenzweig, The Star of Redemption, 128.

${ }^{84}$ RosenZweig, Zweistromland, 154.

${ }^{85}$ Franz Rosenzweig, כוכב הגאולה [Kokhav ha-ge'ulah] [The Star of Redemption in Hebrew version], ed. Yehoshua Amir (Jerusalem: Byalik Institute, 1970), 205, footnote 11.

${ }^{86}$ Ibid, p. 134.

${ }^{87}$ Ibid, p. 196. 
might make the same remark, and with no consequence, because it is not a confession to a revealed God, but a hidden one, as is the case in paganism. ${ }^{88}$

To be sure, the renewed interest in Islam in recent decades would not have been of such magnitude and intensity had it not been for the manifestations of extreme violence by individuals and groups in the name of Islam. Indeed, the current geo-political reality has fueled scholarly interest and energies to find the right set of discourses to understand what had heretofore been a mysterious non-Western religious phenomenon. Indeed, a variety of commentators in manifold academic fields are still struggling to make sense of the connection between Islamic theology and current extremist politics. We frequently hear the apocalyptic reflections of religious leaders - as for example the Pope Benedictus, as well as charismatic spokesmen of the evangelical movement - with their almost hysterically proclamations echoing age-old anti-Islamic polemic by medieval Christian thinkers.

At the same time another strain of academic work on Islam has emerged namely its appropriation into the emerging interdisciplinary discourses. Among Rosenzweig's critics mentioned above, Jean Cahan explicitly employs languages of this trend as a means to critique Rosenzweig's position. ${ }^{89}$ For example, she claims that "To contemporary liberal sensibilities, Rosenzweig's conception of Islam is both puzzling and troubling". ${ }^{90}$ The reason

${ }^{88}$ Since Islam is in fact philosophy disguised as theology, Allah is akin to the philosopher's God, an Idea at the peak of a system reached through rational speculation which perceives His existence while not, however, creating any relationship to him. In other words, all the philosophical questions about how God created the world and the like, are questions that direct God as a hidden third person, as an object, outside the reach of human attachment. The implication of this is that like in pagan society, Allah remains hidden because the individual is only a detail in a faceless collective of a race or a country.

${ }^{89}$ Such critics treat Rosenzweig's attitude as a species of what Edward Said called 'Orientalism,' that is as a part of a general tendency by Western writers in recent centuries to describe Islam and the Arab world through the prejudices of their own culture. For example, Cahan observes that the political consequence that follows from Rosenzweig's stereotypical description of Islam, help reinforce control over those being described (CAHAN, "Rosenzweig's Dialectic," 2, 3). From my perspective, however, Cahan's critique is baseless, for Rosenzweig saw the Jewish people as having pursued conquest in its far, mythological past, what makes it, in his opinion, the paradigmatic pacifist people. Moreover, it was Judaism and Christianity that he saw as representing 'non-Western' forces (übereuropäischen, übermenschlichen Mächten), part of the last life-line to a disintegrating Western culture (RosenZweIG, Briefe und Tagebücher, 2. Band, 889 ), that is, of a West in the process of being conquered by non-Westerners.

${ }^{90}$ CAHAN, "Rosenzweig's Dialectic," 19. She admits that her scholarship is informed by an identification with recent political and literary theorists who are concerned with liberalism and justice among individuals and groups from divergent backgrounds, commitments and loyalties, and for whom further, the ideal of equality consists in treating all human beings with equal respect and concern and as ends in themselves (ibid., 2). 
I highlighted this issue of liberal approach is that sometimes it seems to me that what originally started as a positive plural trend to respect differences, became an obsessive and domineering attitude, that is, a paradigmatic discourse that attempts to become "normal discourse" that filters out rhetoric and rationale that might "endanger the general agreement."

In my view, this is akin to the critique against Hannah Arendt's approach to history, as some dismissed as "Journalism," that is, it does not deserve a scholarly effort. And as in Arendt's critique of Zionism, so is the case with Rosenzweig and Islam, namely they are both original and creative, and yet provocative. However, as we have witnessed recently a "Renaissance of Arendt" due to a new atmosphere that created conditions for scholars (mainly in Israel) to re-examine her arguments, I suggest to re-asses Rosenzweig's non-orthodox approach ${ }^{92}$ as a resource for understanding the current civilizational debate with Islam today.

Before I turn to that, it should be noted that the study case I present here does not necessarily aim to formulate a new ground for a so called interfaith dialogue with Islam. This relatively new branch of theology presupposes an encounter between different theological contents that share the same ends, which Rosenzweig is not interested to do. As we have seen, he claims that Islam does not address the Judeo-Christian kingdom of God. ${ }^{93}$

${ }^{91}$ See Conor Cruise O'Brien, On the Eve of the Millenium: The Future of Democracy through an Age of Unreason (New York: The Free Press, 1994), 154-159.

${ }^{92}$ Gesine Palmer suggests that though Rosenzweig's attitude towards Islam (as well as Christianity and Judaism) was not developed through the then accepted methods of religious science (elaborating nuances that distinguish between religions), nonetheless, his analysis of the three faiths contributes to the understanding of the developments that take place within them (Schwartz and Palmer, Franz Rosenzweig. "Innerlich bleibt die Welt eine," 10).

${ }^{93}$ While conscious dialogical-existential elements are embedded in Rosenzweig's approach to religion, as clearly manifested in his conception of Jewish law (in regard to kosher food as a separating factor between Jews and Gentiles, see his Letter to Edith Hann from January 13, 1920, in Horwitz (ed.), F. Rosenzweig Briefe und Tagebücher [Auswahl], 184; Regarding the future of the Jewish law, see Letter to Joseph Prager from July 24, 1925, ibid. 351; see also Rosenzweig's argument in his Die Bauleute written in 1923 in response to Buber's objective conception of the commandments, that contrary to Kant's categorical imperative which addresses an abstract human being, the Jewish commandment is personal), commentators like Schweid claim that Rosenzweig was locked within his own unpluralistic system. Eliezer SchweID, Toldot philosophiat Hadat Hayehudit bazman Ha-chadash [A History of Modern Jewish Religious Philosophy], Part 3 (2) (Tel Aviv: Am Oved, 2005), 119-120. Hence, in my opinion, we are left here with two strategic options: 1) To read Rosenzweig's work in a "non-Rosenzweigian" way, that is, to rescue his existential concept and adjust it into the framework of interfaith discussion. For example, his characterization of Islam as polytheistic religion despite its apparent zeal for Allah's unity, due to his observation that the Muslim believer is not in a relationship with Him, can serve as an alter- 
In my opinion, Rosenzweig's message that can make sense of the present, can be reduced to the following question, if to use Arendt's attitude again: how to live as a religious community in a shared world, that is to take into account the opinions of "others"? or alternatively: is it possible to think of non-violent monotheistic mission?

I will demonstrate this message with the help of David Goldmann's analysis of a specific prominent area in Europe's political agenda today, in part in light of Muslim immigration, namely the issue of extreme religious violence. Among cultural critics, a consensus has emerged that it is possible to isolate Islamic violence issues from all other aspects of contention around Islam, that such violence will, in the end, resolve in a satisfactory manner. The assumption embedded in this logic is that despite the explicit rhetoric of radical Muslims, Islam is governed by cautious, peace-seeking democratic people, who if offered sufficient incentives and pacifying entreaties would respond with their own pragmatic initiatives. Academics (and other intellectuals) advocating their post-colonial methodologies ardently support this view. ${ }^{94}$

According to Goldmann, the question raised by Islamic forms of violence - including honor killings and the like-appears, on the surface, to be whether Muslims commit such acts because they are bad Muslims or because they are good ones. Goldmann argues, however that this is in fact the wrong question, for Islam in its very nature, cannot be separated from what he calls primitive life. The death penalty for adultery, as in Islamic law, is typical, for Goldmann, of a primitive society. To be sure, a similar punishments is found in the Hebrew Bible, but the actual enactment of such a penalty was extremely rare in the Jewish Commonwealth. ${ }^{95}$

The question that ought to be asked, following Goldmann, is why the practices of pagan society endure in the Islamic world while they have been

native basis for a discussion about the nature (and purpose) of religion at all. 2) Reading Rosenzweig "as he realiy was," that is to use his thesis on the hierarchical order of the Abrahamic religions (as I will demonstrate in the following) to move the discussion on Islam into the cultural realm. The reference to Islam as a cultural category allows for any inclusive efforts to focus on its worldly qualities such as its achievements in art, politics, architecture and more.

${ }^{94}$ See Michael WidLanski, Battle for our Minds: Western Elites and the Terror Threat (New York: Threshold Editions, 2012), 19-43.

${ }^{95}$ To support his argument, Goldmann brings proof from Hillel's time, a generation before Jesus, where the proverbial wisdom was that a court that handed down a single death sentence in a century was considered to be a 'hanging' court. Furthermore, Jesus' mercy towards the adulteress reflected a wide body of Second-Temple opinion. For centuries, no Christian court has condemned a woman to death for adultery; neither is there record of such a sentence by any Jewish court. 
all but eliminated in the Judeo-Christian world (though one should note that the Shariah is a controversial issue among the progressive Muslim scholars). It is here, claims Goldmann, Rosenzweig's understanding of the problem of the three Abrahamic religions' relationship to gentile society-comes in. ${ }^{96}$ Although elements of traditional practice are found in ancient Jewish law, by electing Israel, God removes it from the surrounding world of pagan practices. ${ }^{97}$ Unlike Judaism, Christianity proposes to incorporate all of humanity into the new People of God, by effecting an inner transformation of every individual. By this transformation, Christianity rejects conventional society and culture all the more emphatically. To become a Christian, every individual must repudiate ethnicity and be reborn into a spiritualized Israel. The reborn Christian belongs not to a tribe, but to the people of God. ${ }^{98}$

Islam, by contrast, with what Rosenzweig sees as the distinctive lack of focus on the existential, ${ }^{99}$ offers a universal religion not of inner

\footnotetext{
${ }^{96}$ According to Goldmann, contemporary academic criticism of Rosenzweig's view of Islam, including those who have made genuine efforts to understanding the Star, can claim no validity, in so far that they fail to recognize what for Rosenzweig was central - the conception of human responses to God shared by both Christians and Jews, and its fundamental difference to that of Islam. He notes, for example, that although Gesine Palmer and Yossef Schwartz have collected every passage that mentions the word Islam in Rosenzweig's work (see Schwartz and PALmer, Franz Rosenzweig. "Innerlich bleibt die Welt eine," 35-110), they exclude his striking portrayal of pagan society, and in so doing excise an important context through which Rosenzweig understood Islam. In seeing Islam and paganism on the same continuum, he excludes the former from the distinctive theology reflected in both Judaism and Christianity where the soul's awareness of God begins with His love, and from which arise both faith and authentic human individuality. The existential condition of being loved is what uniquely characterizes both Christian and Jew, as opposed to the pagan, for whom God must always remain hidden.

${ }^{97}$ Rosenzweig, The Star of Redemption, part 3, book 1.

${ }^{98}$ Ibid., part 3, book 2.

${ }^{99}$ According to Goldmann, Rosenzweig's more important innovation - in fact the real challenge to any theological dialogue with Islam - is in his showing, by emphasizing experiential or existential aspects, that the difference between the Judeo-Christian West and Islam is more than merely a historical matter (as religious studies conventionally has tried to understand it). Instead, Rosenzweig suggested a different category, namely religious existentialism (a sociological approach, or phenomenology), with its emphasis on the specificity of the individual's experience. While for Karl Barth, for example, it all begins with God, from the metaphysical, the eternal truth of God's word in the Bible, that is God exists above man's disability, which is why theology and philosophy are separated, with theology towering the latter, For Rosenzweig (as with Paul Tillich) it all begins with the human condition, that is the emphasis is on how God is present in specific human situations. Through this argument, Rosenzweig revealed a missing stage in the relation between the Muslim and God. This crucial aspect of Rosenzweig's thought, has been considered, apart from Goldmann, only by Lehmann ("Rosenzweigs Kritik am Islam," 341). This original approach, Lehmann argues, overshadows its apparent lack of attention to historical details, which others have claimed led to a presentation of Islam more homogenous than it is in actual fact (Ibid., 360).
} 
transformation but of obedience. Precisely this form of universalism ensures that Muslims carry the baggage of traditional life and culture into the new religion, for, in some sense, it offers no point of departure from the traditional (pagan) society which it ostensibly abandons. As a universal religion, it can only universalize the aspirations of the tribes it assimilates, rather than transform them. Older traditional cultural values continue in Islam under the aegis of an Abrahamic monotheism, because the religion allows for their persistence. ${ }^{100}$

Through Goldmann's example, we can clearly see the fundamental difference between Islam on one hand, and Judaism and Christianity on the other - a distinction emanating from Rosenzweig's Star. Through his sharp eye, Rosenzweig provided a concrete phenomenology of religious experience, not through mere abstractions and prejudices. Written by a Jew from a non-Jewish point of view, ${ }^{101}$ there is no vestige of what today goes by the name of Islamophobia, nor any indication of Jewish or European condescension towards Islam. Moreover, as Goldmann observes, from Rosenzweig's observation that Islam was in the past more humane and tolerant than Christianity, we can clearly see that he cannot be termed an "Islamophobe". Indeed, as Matthias Lehmann notes, Rosenzweig has proven through his favorable comments about Islam, that he was able to separate theoretical clichés from historical realities.

On the other hand, Wayne Cristaudo's enthusiasm for supporting Rosenzweig's views through citing historical and current examples of Muslim violence, and their invocation of classical Muslim texts (not mentioned by Rosenzweig himself) for their justification, echoes the choir of the non-dialogical fundamentalist Christian camp. That is, Cristaudo elaborates a perspective essentially like that of Martin Brasser, leading to the conclusion that Rosenzweig's parodic presentation of Islam is a serious obstacle to the interfaith development. ${ }^{102}$ Admittedly, the catastrophic events with which Islam's name has been associated in the last decades, elicit support for Cristaudo's sympathetic reading of Rosenzweig, the latter's conclusions

\footnotetext{
${ }^{100}$ Spengler [David. P. Goldmann], “Should Islam be blamed for 'barbaric' acts?”, The Asia Times Online (March 2008), accessed October 8, 2020, http://www.atimes.com/atimes/Middle_ East/ JC11Ak04.html.

${ }^{101}$ Goldmann adds that those of Rosenzweig's critics who argue that Islam served as a mere incidental example for his discussions of revelation and idolatry, ignore the fact that Rosenzweig emphasized in his essay "The New Thinking" that The Star was not a Jewish book. Indeed, while it deals with Judaism, it deals equally with both Christianity and Islam.

${ }^{102}$ BRASSER, "Rosenzweig und die Karikatur des Islam," 152.
} 
today seeming not unrealistic. Yet, his commentary looks like a recipe for a contemporary political agenda, serving among other things as a guide to ward off the extremes of Islam. I would prefer, however, to invoke Martin Buber's approach, according to which reproach is not merely a form of apologetics, but rather part of a dialogue - an approach he himself applied in relationship to Christianity, as well as Rosenzweig in his relationship with his friend Eugen Rosenstock who converted to Christianity. From Martin Buber's perspective, an interreligious approach that claims that theological conflicts should be left out of any discussion, is a misguided illusion. Yet Cristaudo's often brazen polemics make it nearly impossible to use Rosenzweig's theological critique as part of a future discussion with Muslims.

Finally, when Rosenzweig's relatively conservative style is compared to the controversial deconstructive approach to the history of Islam taken by few contemporary historians such as John Wansbrough (Quranic Studies: Sources and Methods of Scriptural Interpretation, 1977; The Secterian Milieu: Content and Composition of Islamic Salvation History, 1978), Michael Cook and Patricia Crone (Hagarism: The Making of the Islamic World, 1977), and the Orientalist Albrecht Noth (Quellenkritische Studien zu Themen, Formen und Tendenzen frühislamischer Geschichts-überlieferung, 1973), Rosenzweig's methodological approach no longer stands out as particularly extreme. This is especially true since Rosenzweig provided a critique of Islam from a purely religious perspective, during a time when contemporary Orientalists, freed from the medieval religious controversies which characterized their predecessors, had moved on to evaluating Islam from a secular perspective, employing all of the available methodological tools of cultural criticism.

\section{BIBLIOGRAPHY}

AnIDJAR, Gil. The Jew, The Arab: A History of the Enemy. Stanford, CA: Stanford University Press, 2003.

Brasser, Martin. "Rosenzweig und die Karikatur des Islam: Negative Konstruktionen im interreligiösen Dialog." Rosenzweig Yearbook 2 (2007): 128-152.

CAHAn, Jean Axelrad. "Rosenzweig's Dialectic of Defiance and Critique of Islam." Journal of Jewish Thought and Philosophy 9, no. 1 (1999): 1-20. DOI: 10.1163/105369900790232392.

Cristaudo, Wayne. "Rosenzweig's Stance toward Islam: The »Troubling Matter« of the TheoPolitics in The Star of Redemption." Rosenzweig Yearbook 2 (2007): 43-86. 
Franz Rosenzweig. Der Mensch und sein Werk. Gesammelte Schriften I-IV. Hague: Martinus Nijhoff, 1976-1984:

I. Briefe und Tagebücher. 1. Band: 1900-1918. 2. Band: 1919-1929. Edited by Rachel Rosenzweig and Edith Rosenzweig-Scheinmann with the cooperation of Bernhard Casper. Hague: Martinus Nijhoff, 1979.

II. Der Stern der Erlösung. Introduction by Reinhold Mayer. Hague: Martinus Nijhoff, 1976 [4 $4^{\text {th }}$ edition].

III. Zweistromland. Kleinere Schriften zu Glauben und Denken. Edited by Reinhold and Annemarie Mayer. Dordrecht: Martinus Nijhoff, 1984.

IV. Sprachdenken im Übersetzen. 1. Band: Jehuda Halevi. Fünfundneunzig Hymnen und Gedichte. Edited by Rafael N. Rosenzweig. Hague: Martinus Nijhoff, 1983. 2. Band: Arbeitspapiere zur Verdeutschung der Schrift. Edited by Rachel Bat Adam. Dordrecht: Martinus Nijhoff, 1984.

GibBs, Robert. Correlations in Rosenzweig and Levinas. Princeton, NJ: Princeton University Press, 1992.

Goldmann, David. P. "Has Franz Rosenzweig’s Time Come?” (1999). Jewish-Christian Relations. Insights and Issues in the ongoing Jewish-Christian Dialogue, http://www. jcrelations.net/Has+Franz+Rosenzweig's+Time+Come\%3F.2195.0.html? L =3.

GoldzIHER, Ignaz. Vorlesungen über den Islam. Heidelberg: Carl Winter's Universitätsbuchhandlung, 1910.

GoLDZIHER, Ignaz. Introduction to Islamic Theology and Law. Princeton, NJ: Princeton University Press, 1981.

Hegel, Georg Wilhelm Friedrich. Vorlesungen über die Ästhetik. Frankfurt am Main: Suhrkamp, 1986.

Hegel, Georg Wilhelm Friedrich. Vorlesungen über die Philosophie der Religion. Hamburg: Felix Meiner Verlag, 1993.

Hegel, Georg Wilhelm Friedrich. Vorlesungen über die Geschichte der Philosophie. Die Philosophie des Mittelalters, (1) Die Arabische Philosophie. In Hegel sämtliche Werke. Bd. 19. Stuttgart: Fromanns Holzboog, 1958.

Hegel, Georg Wilhelm Friedrich. Lesungen über die Geschichte der Philosophie. Zweiter Theil: Die Philosophie des Mittelatlers, 1. Frankfurt am Main: Suhrkamp, 1986.

Horwitz, Rivka (ed.). F. Rosenzweig Briefe und Tagebuecher [Auswahl]. Hebrew edition. Jerusalem: Byalik Institute, 1987.

IRwIN, Robert. For Lust of Knowing: The Orientalists and Their Enemies. London: Penguin, 2006.

Lehmann, Matthias. "Rosenzweigs Kritik am Islam.” Jewish Studies Quarterly 1, no. 4 (1993/ 94): 340-361.

Magonet, Jonathan, Talking to the Other-Jewish Interfaith Dialogue with Christians and Muslims. New York: Bloomsbury, 2003.

Mosès, Stéphane. System and Revelation: The Philosophy of Franz Rosenzweig. Detroit: Wayne State University Press, 1982.

O'Brien, Conor Cruise. On the Eve of the Millenium: The Future of Democracy through an Age of Unreason, New York: The Free Press, 1994.

PINES, Shlomo. "Der Islam im 'Stern der Erlösung.' Eine Untersuchung zu Tendenzen und Quellen Franz Rosenzweigs." Hebräische Beiträge zum Wissenschaft des Judentums deutsch angezeigt 3-5 (1987-89): 138-148. 
Pirkei-Avot [(Hebrew: קָּרְקיקי אָבוֹת; Ethics of the Patriarchs].

Putnam, Hilary. Introduction to Franz Rosenzweig, Understanding the Sick and The Healthy: A View of World, Man and God. Cambridge, MA: Harvard University Press, 1999.

Rosenzweig, Franz. The Star of Redemption. Translated by Barbara E. Galli. Madison, WI: University of Wisconsin Press, 2005.

Rosenzweig, Franz. כוכב הגאולה [Kokhav ha-ge'ulah] [The Star of Redemption in Hebrew version]. Edited by Yehoshua Amir. Jerusalem: Byalik Institute, 1970.

Rosenzweig, Franz. Zweistromland. Kleinere Schriften zu Glauben und Denken. Edited by Reinhold and Annemarie Meyer. In Franz Rosenzweig. Der Mensch und sein Werk. Gesammelte Schriften. Bd. III. Dordrecht: Martinus Nijhoff, 1984.

Rosenzweig, Franz. Hegel und der Staat. Berlin: Suhrkamp, 2010.

Samuelson, Norbert M. A User's Guide to Franz Rosenzweig's 'Star of Redemption.' Abingdon, Oxon: Routledge, 1999.

Schwartz, Yosef, and Gesine Palmer (eds.). Franz Rosenzweig. "Innerlich bleibt die Welt eine." Ausgewählte texte zum Islam. Berlin, Wien: Philo Verlagsgesellschaft, 2003.

SchweID, Eliezer. Toldot philosophiat Hadat Hayehudit bazman Ha-chadash [A History of Modern Jewish Religious Philosophy. Part 3 (2). Tel Aviv: Am Oved, 2005.

Spengler [Goldmann, David P.]. "Should Islam be blamed for 'barbaric' acts?" The Asia Times Online (March 2008). Accessed October 8, 2020. http://www.atimes.com/atimes/Middle East/ JC11Ak04.html.

Widlanski, Michael. Battle for our Minds: Western Elites and the Terror Threat. New York: Threshold Editions, 2012.

\section{ROSENZWEIG'S CRITIQUE OF ISLAM AND ITS VALUE TODAY}

\section{S u m m a ry}

This article focuses on Franz Rosenzweig's radical provocative views of Islam, which ironically appears in his magnum opus The Star of Redemption (1921), a work considered groundbreaking in its interfaith dialogical approach. The article opens with a short presentation of their main (more popular) point, and the alleged problematic nature of their attitude and style. At this stage I concisely review the evolution of the reference to these views in the scholarship, since the appearance of The Star of Redemption to our day in the late postmodern age. In regard to the relation of the current article to existing literature, it should be noted that it is drawing on insights from a host of different primary and secondary related sources. In addressing the question of the acceptance of Rosenzweig's approach, I refer to opinions of a line of thinkers, which re-appear in the following discussions throughout the article. In particular cases, such as in the concluding section, I mention some more background sources to support my argument. I obviously quote the sources from the Old and New Testaments and the Quran upon which Rosenzeig's thesis rests. I close the outlining of the article's framework with a formulation of its purpose, namely to gain clarity of Rosenzweig's insights in order to ultimately speculate on its place in contemporary discourse on Islam.

Coming across Franz Rosenzweig's, the modern Jewish theologian and philosopher mostly associates with his revolutionary dialogic approach to Christianity, opinions of Islam, one would probably consider him nothing more than another Islamophobe. This may explain the relatively low interest research has for this aspect of his thought, his radical approach considered con- 
descending and his treatment of the subject considered superficial and patronizing. All the more when these insights are found in his The Star of Redemption, considered to be a treatise that opened a new era in the relationship between Judaism and Christianity, setting them as complementary and equal, which no Jewish thinker before him had dared do. The purpose of my paper is to clarify his insights on Islam in The Star, and to explain what can such a view contribute on this topic today, its controversial approach notwithstanding.

Key words: Rosenzweig; Islam; criticism; controversial approach; relevance to contemporary discourse.

\section{ROSENZWEIGA KRYTYKA ISLAMU \\ I JEGO WARTOŚĆ DZISIAJ}

\section{Streszczenie}

Autor artykułu skupia się na radykalnie prowokacyjnym postrzeganiu islamu przez Franza Rosenzweiga, które w ironicznej formie pojawia się w jego opus magnum, czyli The Star of Redemption (1921), pracy uznanej za przełomową w podejściu do dialogu międzywyznaniowego. Artykuł otwiera krótka prezentacja głównego (bardziej popularnego) punktu widzenia oraz rzekomej problematyczności takiej postawy i stylu. Autor dokonuje zwięzłego przeglądu ewolucji odniesień do tych poglądów w badaniach — od pojawienia się The Star of Redemption do naszych czasów w późnej epoce ponowoczesnej. Co do odniesień niniejszego artykułu do istniejącej literatury należy zauważyć, że opiera się on na spostrzeżeniach z wielu różnych pokrewnych źródeł pierwotnych i wtórnych. Odnosząc się do kwestii akceptacji podejścia Rosenzweiga, odwołuje się do opinii pewnej grupy myślicieli, które powracają w kolejnych zagadnieniach w całym artykule. W szczególnych przypadkach, na przykład w części podsumowującej, na poparcie swojej argumentacji autor wymienia kilka dodatkowych źródeł. Oczywiście cytuje źródła ze Starego i Nowego Testamentu oraz Koranu, na których opiera się teza Rosenzweiga. Artykuł zamyka sformułowanie jego celu, a mianowicie uzyskania klarowności w postrzeganiu Rosenzweiga, aby ostatecznie móc spekulować na temat jego miejsca we współczesnym dyskursie na temat islamu.

Franza Rosenzweiga, współczesnego teologa i filozofa żydowskiego, który kojarzy się głównie $\mathrm{z}$ jego dość rewolucyjnym, dialogicznym podejściem do chrześcijaństwa, w jego poglądach na temat islamu można by uznać po prostu za islamofoba. Może to wyjaśniać stosunkowo małe zainteresowanie badaniem jego myśli w tym aspekcie, radykalne podejście do protekcjonizmu oraz powierzchowne i protekcjonalne podejście do tematu. Tym bardziej że te spostrzeżenia znajdują się w jego The Star of Redemption, uważanej za traktat, który otworzył nową erę w stosunkach między judaizmem a chrześcijaństwem, ustawiając je jako komplementarne i równe, na co nie odważył się przed nim żaden żydowski myśliciel. Generalnie celem autora jest wyjaśnienie poglądów Rosenzweiga na islam w jego The Star of Redemption i sprecyzowanie, co owe poglądy mogą wnieść do dyskusji na ten temat dzisiaj, pomimo kontrowersyjnego podejścia.

Słowa kluczowe: Rosenzweig; islam; krytyka; kontrowersyjne podejście; odniesienie do współczesnego dyskursu. 